\title{
'Made-in-transit' Yoghurt Processing: A Review of Basic Concepts and Technological Implications
}

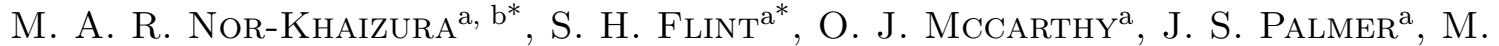 \\ GOLDING $^{\mathrm{a}}$, AND A. JAWORSKA ${ }^{\mathrm{c}}$ \\ ${ }^{a}$ Institute Food, Nutrition and Human Health to Massey Institute of Food Science and Technology, Private \\ Bag 11 222, Palmerston North 4442, New Zealand \\ ${ }^{\mathrm{b}}$ Faculty of Food Science and Technology, Universiti Putra Malaysia, 43400 Serdang Selangor, Malaysia \\ ${ }^{\mathrm{c}}$ Designer, $1011 \mathrm{HW}$ Amsterdam, the Netherlands \\ ${ }^{*}$ Corresponding author \\ norkhaizura@upm.edu.my \\ TEL: +60389468533 \\ FAX: +60389423552
}

Received: 10 November 2017; Published online: 18 October 2018

\begin{abstract}
The manufacture of food during distribution, a concept known as "made-in-transit" (MIT) manufacture, has the potential to expand the distribution range, extend shelf-life, and provide the customer with the freshest possible product. Benefits for the manufacturer include maximising throughput while minimising manufacturing space and inventory. This concept is new, with mushrooms being the only MIT food developed so far. The feasibility of developing an MIT product from a fermented food was reviewed using yoghurt as a model system. Through the alteration of some of the yoghurt manufacturing parameters (e.g. milk base formulation, heat treatment, starter culture composition and fermentation temperature) it is possible to develop this form of yoghurt production. A predictive microbiology approach is suitable for predicting the effects of both time and temperature on designing and predicting the fermentation process. This review demonstrates the potential of the MIT concept for a fermented food.
\end{abstract}

Keywords: Made-in-transit (MIT); Fermentation; Yoghurt; Predictive microbiology

\section{Fundamental features of MIT}

Made-in-transit (MIT) is a supply chain concept in which the production or manufacture of a perishable food occurs partially or completely during transportation (Jaworska, 2007a). The MIT concept transforms manufacture where manufacture is merged with distribution. This has the potential to change the role of transportation from simply relocating material to include manufacture (Jaworska, 2007a). Jaworska (2007b). In such processes transportation has been described as a productive creator of value by taking a to-

Copyright C)2018 ISEKI-Food Association (IFA) tal chain perspective from the outset and skipping, merging or reversing the order of events. The MIT concept is an example of convergent technology where two or more activities are combined into one. Traditionally, product shelf-life is reduced by the time taken for transportation. While, the MIT concept avoids this loss of shelflife and provides an opportunity for the consumer to harvest the fresh end product themselves. 


\section{Application and advantages of MIT}

One application of this concept is the growth of mushrooms which can occur in packs within 5 to 7 days during transportation. If packages arrive prematurely at the retailer's facility, the last part of growth could occur there (Jaworska, 2008). Consumers may wish to purchase before the "ready by" date and pick product units that suit their need, based on their planned time of consumption. The MIT concept has the potential to make use of a "ready by" date in preference to a "use by" date. This ensures that the consumer receives a fresh product ideal for consumption. There are several other benefits of MIT (Jaworska, 2007a, 2007b);

1. Reduced factory manufacturing and inventory space

2. Growth-enabling technology replacing postharvest technology for plant produce

3. Expanding the distribution range of the product by making use of the manufacturing time for transportation

4. Extending the shelf-life as the product arrives at the retailer's facilities in a fresher state than would be possible if manufacture and distribution occurred in the normal sequence.

5. Preventing overproduction and consequent waste, when applied to on-demand supply chains, and

6. Providing higher quality, freshness and nutrient-rich products to the consumer.

\section{Challenges of MIT}

Jaworska (2007b) mentioned that experts have raised a concern about the ability of the product to stand the vibration of transport. In the case of mushrooms, one concern was that the bodies of the mushrooms during growth may be too brittle and this may result in damage during the transportation. It was hypothesized by another researcher that any damage may depend on the stage of development. The diverse species of mushroom mean the some may be more tolerant than others to vibration during transportation (Jaworska, 2007b).

Other challenges of producing MIT product are; producing a consistent product, applying special packaging to ensure ideal conditions for manufacture, controlling the conditions surrounding the package (i.e. environment) and changing the standard system of production and distribution. Many of the systems are in place but not being used in the right way for MIT. For example, containers are available with the capacity to control the environment (humidity, temperature, carbon dioxide levels) to preserve freshness of product rather than being set to enable manufacture (Jaworska, 2008).

As MIT is considered a new concept, research on potential applications is limited. Yet, some of the issues facing manufacturers for product distribution could possibly be resolved through applying the MIT concept. For instance, New Zealand is a long way from world markets and this is a challenge for NZ manufacturers to market their product outside New Zealand. The MIT concept would allow food manufacturers to make use of the time a product is in transit to distant markets. As much food is discarded as it exceeds the 'best before' date in the market (Kleijnen \& Van der Vorst, 2005) and home (Parfitt, Barthel, \& Macnaughton, 2010), product manufactured using the MIT concept may avoid some wastage of food.

\section{Potential of MIT in food system}

To the authors' knowledge, the concept of MIT is currently only applied to mushrooms. There is potential to apply the MIT concept to many foods. Such foods need to be capable of transformation or maturity during transport. Potential foods most suited to MIT are fermented products like cheese, salami, fermented drinks and yoghurt (Table 1). Among all fermented products, yoghurt and cultured dairy products are the fastest growing dairy categories worldwide (Oneil, Kleyn, \& Hare, 1979). In one article the Fonterra Brands Managing Director (Anonymous, 2005) mentioned that yoghurt is not only 
well received locally but has a potential to be applied in markets outside New Zealand. Hence, yoghurt could be a suitable model of fermented product to be manufactured using the MIT concept, extending the distribution of yoghurt from New Zealand. Yoghurt has a worldwide market as a fermented product yet has a short shelf-life. As yoghurt has a rapid fermentation time, it was selected as a suitable food for this feasibility study as results could be obtained in a short time frame (Nor-Khaizura, 2013).

To apply the MIT concept to yoghurt, fermentation needs to be carried out during distribution. Generally, the fermentation lasts for 6 to $12 \mathrm{~h}$ in the processing plant, which, for the MIT concept, would only allow only a short distribution of the product. Manipulation of crucial factors including milk base composition, heat treatment, starter culture composition and inoculum size (Tamime \& Robinson, 2007) could extend the fermentation to give a yoghurt that could be used to test the feasibility of the MIT concept (Nor-Khaizura et al., 2012).

\subsection{Yoghurt}

Yoghurt is one of the best known and most popular cultured milk products internationally. Data provided by the USDA reveals that yoghurt consumption in the US gradually increased from 1954 to 2005 (Figure 1). Various factors influence the consumption of fermented milk, particularly yoghurt. These include the availability of milk, food habits, level of income, advertising, range of fermented milk products available in the market, distribution system and general acceptability of other dairy products (Kurmann, 1984).

Yoghurt is produced by the growth of Streptococcus thermophilus and Lactobacillus delbrueckii subsp. bulgaricus in heated milk (Kosikowski \& Mistry, 1997) incubated at the optimum conditions of 40 to $45^{\circ} \mathrm{C}$ for 2 to 3 hours (Tamime \& Robinson, 2007). During this time, the starter culture metabolizes lactose in the milk, producing the lactic acid which reduces the $\mathrm{pH}$ of milk to $\mathrm{pH}$ within 4.6 to 4.2 (Tamime \& Robinson, 2007). This is the major determinant in producing the characteristics of yoghurt terms of the flavour and texture. Damin, Alcantara, Nunes, and Oliveira (2009) described the texture of yoghurt resulting from the curdling of milk that occurs when casein becomes unstable and coagulates to form a firm gel. This gel is composed of strands of casein micelles and whey entrapped within this matrix. This matrix consists of, 1) the disulphide bonding between $\mathrm{k}$-casein and denatured whey protein and 2) casein aggregation when the $\mathrm{pH}$ decreases to the isoelectric point of casein. Lactic acid also plays a major role in the preservation of the product by creating a $\mathrm{pH}$ that limits the growth of many microorganisms, including pathogens (Walstra, 1999). The shelf-life of yoghurt is about 20 days under refrigeration. (Oneil et al., 1979).

Yoghurt can be categorized due to its physical, chemical or flavour properties. Physically, yoghurt may be a set yoghurt with firm gel, a stirred yoghurt with smooth gel in which the gel has been broken or as drinking yoghurt with a viscous liquid (Spreer, 2017; Tamime \& Robinson, 2007). Chemically, yoghurt may be a full, low or non-fat product. Flavour may be described as plain or natural or with fruit and other flavourings (Tamime \& Robinson, 2007). Commercially, yoghurt processing involves the standardisation of milk, homogenization, heat treatment, inoculation of starter culture, fermentation, cooling and packaging. To adapt the MIT system to yoghurt processing, yoghurt fermentation could be carried out during distribution. Since the current fermentation time is very short, less than $12 \mathrm{~h}$, an extended fermentation would be required in order to expand the yoghurt distribution and shelf-life. There are a number of challenges in preparing an MIT yoghurt, in particular controlling the growth of contaminants and ensuring the final product is acceptable in terms of the physical and flavour characteristics. The steps in yoghurt manufacture, including milk standardization, heat treatment, starter culture composition and inoculum level, and fermentation temperature could be altered to extend the fermentation time. These factors will affect the acidification and gelation processes (Peng, Serra, Horne, \& Lucey, 2009). 
120 Nor-Khaizura et al.

Table 1: Examples of Fermented foods: substrate, cultured microorganism(s) and country

\begin{tabular}{|c|c|c|c|}
\hline Product & Substrate & Cultured Microorganism(s) & Main Market \\
\hline Yoghurt & Milk & $\begin{array}{l}\text { Streptococcs thermophilus, Lactobacillus } \\
\text { delbrueckii subsp. Bulgaricus }\end{array}$ & Worldwide \\
\hline Acidophilus milk & Milk & Lactobacillus acidophilus & Several countries \\
\hline Cheese & Milk & $\begin{array}{l}\text { Lactic acid bacteria (L. lactis, S. thermophilus, L. shermanii, } \\
\text { Propionibacterium) sometimes moulds (Penicillium spp.) }\end{array}$ & Worldwide \\
\hline Fermented sausages & Meat & $\begin{array}{l}\text { Lactic acid bacteria (lactobacilli, pediococci) Catalase positive cocci } \\
\text { (S. carnosus, S. xylosus, M. varians) sometimes yeasts and/or moulds }\end{array}$ & Europe and United State \\
\hline Soy sauce & Soybeans and wheat & $\begin{array}{l}\text { Aspergillus oryzae or A. soyae, Lactobacillus, } \\
\text { Zygosaccharomyces rouxii }\end{array}$ & The Orient (Japan, China, Philippines) \\
\hline Bread & Wheat, rye, other grains & Saccharomyces cerevisiae, other yeasts, lactic acid bacteria & Worldwide \\
\hline Sauerkraut & Cabbage & $\begin{array}{l}\text { Lactic acid bacteria Ln. mesenteroides, L. brevis, L. plantarum, } \\
\text { L. curvatus, L. sake }\end{array}$ & Worldwide \\
\hline Kimchi & $\begin{array}{l}\text { Cabbage, vegetables, } \\
\text { sometimes seafood, nuts }\end{array}$ & Lactic acid bacteria & Korea \\
\hline
\end{tabular}

Source: Adapted from Doyle, Beuchat, and Montville (1997) and Jay (2000)

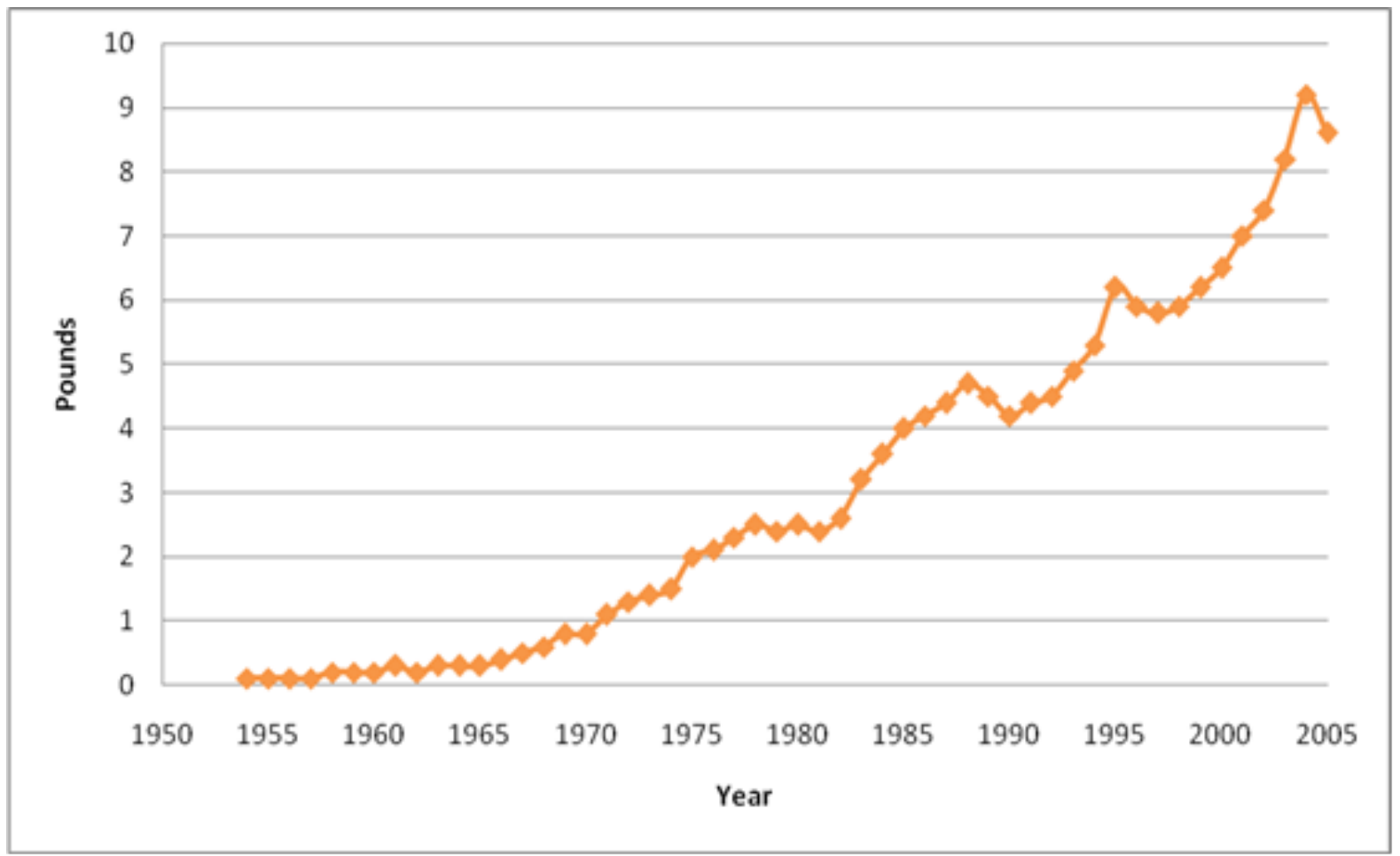

Figure 1: Per capita yoghurt consumption in United State from year 1954 to 2005 (Source: Economic Research Service, USDA 


\subsection{Factors affecting yoghurt fermentation}

\section{Milk standardization}

The main and most crucial ingredient in yoghurt processing is milk. Milk composition is described in terms of milk fat and milk solids not fat (MSNF) which consists of protein, lactose and minerals. Standardization of fat and MSNF content in milk is essential in yoghurt manufacture as this influences the quality and consistency of the end product. The fat content of yoghurt varies, from as low as 0.1 to $10 \mathrm{~g}$ per $100 \mathrm{~g}$ depending on the type of yoghurt; full, medium or low-fat yoghurt (Tamime \& Robinson, 2007). The percentage of MSNF (mainly lactose, protein and mineral matter) in milk for yoghurt manufacture depends on the legal standards of the country in which the product will be sold or the physical or flavour of the end product. The major component in milk is water (84.5 to $87.7 \%$ ) (Swaisgood, 1996). Next is lactose (4.9 to $5.0 \%$ ), the major carbohydrate of milk. Lactose is essential in yoghurt production by providing the nutrition or energy source for the yoghurt starter bacteria. Fat 3.4 to $5.1 \%$ ), imparts richness or smoothness to dairy products and directly provides an excellent mouthfeel. Protein (3.3 to $3.9 \%$ ) plays an important role in the formation of the coagulum, influencing the consistency or viscosity of yoghurt (Tamime \& Robinson, 2007). The level of protein is proportional to the viscosity of yoghurt. The major proteins of milk are caseins and whey proteins. Caseins are insolubilized protein and begin to precipitate when the $\mathrm{pH}$ of milk is reduced to $\mathrm{pH}$ 4.6. The soluble portion at $\mathrm{pH} 4.6$ is known as whey proteins consisting of albumins and globulins (Chandan \& O'Rell, 2006). The total solids content of the milk base influences the yoghurt firmness (Penna, Converti, \& De Oliveira, 2006; Tamime \& Deeth, 1980; Nor-Khaizura et al., 2012). The milk base protein content (Tamime, Kalab, \& Davies, 1984; Trachoo \& Mistry, 1998) and protein type (Cho, Lucey, \& Singh, 1999; Penna et al., 2006; Sodini, Remeuf, Haddad, \& Georges, 2004; Tamime et al., 1984) are important factors in determining yoghurt texture.

The use of a reconstituted yoghurt milk base pre- pared from dried dairy ingredients is an alternative to standardised fresh milk. Skim milk powder (SMP) is widely used to prepare a yoghurt milk base (Isleten \& Karagul-Yuceer, 2006). These authors also mentioned that the sensory properties of reconstituted milk ideally should be similar to fresh skim milk. The use of SMP is preferable to whole milk for the manufacture of fermented milks due to problems with oxidized flavours (McKenna, 1997; McKenna \& Anema, 1993). The milk powder should be free from any inhibitory agents and have good microbiological and physical quality. Some specific requirements for SMP include a whey protein nitrogen index of 4.5-5.9; cysteine number, 38-48; thiol number, 7.5-9.4 and heat number, 80-83 (Wilcek, 1990). In the preparation of reconstituted skim milk from SMP, the hydration time is crucial in order to achieve the proper re-equilibration of the minerals, which requires around $3 \mathrm{~h}$ (Anema \& $\mathrm{Li}, 2003)$. The normal practice is to rehydrate the powder to about $12 \mathrm{~g}$ per $100 \mathrm{~g}$ solid nonfats (SNF) (Tamime \& Robinson, 2007). The Codex Standards (FAO/WHO, 2003) state that fermented milk products including yoghurt, must contain a minimum of $2.7 \%$ milk protein (\% $\mathrm{m} / \mathrm{m})$ and less than $15 \%$ milk fat $(\% \mathrm{~m} / \mathrm{m})$.

To ensure the characteristics in yoghurt, stabilizers are often added into the yoghurt milk base. Stabilizers can improve the body and texture, viscosity or consistency, appearance and mouthfeel. Yoghurt coagulum is often subject to mechanical treatment during manufacture, for example stirring the coagulum in the fermentation tank for stirred yoghurt production, mixing to incorporate the fruit or flavours into the coagulum and subsequent post-fermentation treatment of the coagulum (e.g. pasteurization, UHT) (Tamime \& Robinson, 2007). Stabilizers can avoid defects during stirring. Other functions of stabilizers incorporated into the yoghurt mix listed by Chandan and O'Rell (2006) are as follows: minimise whey separation and bind free water, maintain gel structure after pumping, mixing and cooling, and increase shelf-life of the product. Ingredients that are usually added as yoghurt stabilizers are starch, gelatin, guar gum, locust bean gum, carrageenan, pectin and xanthan gum. The addition of stabilizers is not suitable for plain yoghurt as they may affect the 
product aroma and flavour (Tamime \& Robinson, 2007) and may affect the consumer perception of yoghurt (Amatayakul, Sherkat, \& Shah, 2006).

Yoghurt texture can be improved by increasing the milk total solids by three methods 1) concentrating the milk base through evaporation, 2) reverse osmosis ( $\mathrm{RO}$ ) and 3 ) fortification with dried dairy ingredient such as skim milk powder (SMP), skim milk concentrate (SMC) or buttermilk powder (BMP) (Sodini et al., 2004).

Many studies have been carried out to enhance the texture of yoghurt by fortification with dried dairy protein such as skim milk powder (Damin et al., 2009; Guzmán-González, Morais, Ramos, \& Amigo, 1999), buttermilk powder (Trachoo \& Mistry, 1998), whey protein concentrates (Damin et al., 2009; GuzmánGonzález et al., 1999; Lucey, Munro, \& Singh, 1999; Patocka, Cervenkova, Narine, \& Jelen, 2006; Remeuf, Mohammed, Sodini, \& Tissier, 2003), whey protein isolates (Isleten \& KaragulYuceer, 2006; Patocka et al., 2006), milk protein concentrate (Guzmán-González et al., 1999), sodium caseinate (Damin et al., 2009; Isleten \& Karagul-Yuceer, 2006) and other milk-protein based ingredients (Lankes, Ozer, \& Robinson, 1998; Rohm \& Schmid, 1993) These ingredients have gained acceptance as a feasible way to increase total solids in low-fat and non-fat yoghurt (Tamime \& Robinson, 2007). Sodini et al. (2004) also mentioned that the effect of milk base protein enrichment could be influenced by the heat treatment of the milk base.

\section{Fortification with dried dairy ingredient}

Increasing the total solids content in low-fat and non-fat yoghurt will prevent poor firmness and surface whey separation (Lucey, 2002). Skim milk powder (SMP) is dried non-fat milk and is the most commonly used fortification ingredient to increase the total solid content of the yoghurt milk base. Yoghurt fortified with SMP was observed to have a dense matrix, composed of short micellar chains and small micellar clusters (Tamime et al., 1984). Buttermilk powder (BMP) is the by-product of sweet cream butter manufacture. BMP can act as an emulsifier due to the high content of phospholipids (Tamime \& Robinson, 2007). Yoghurt manufactured from a milk base fortified with BMP has been reported as acceptable (Trachoo \& Mistry, 1998).

Whey protein concentrates (WPC) or isolates (WPI) are the by-products from cheese manufacture and often added to a yoghurt milk base (Penna, Baruffaldi, \& Oliveira, 1997). The addition of WPC to the yoghurt milk base can reduce syneresis, increase yoghurt viscosity (Kailasapathy \& Supriadi, 1996) and water holding capacity (Remeuf et al., 2003), yet, the undesirable flavour of WPC can limit its application in food (Damodaran, 1996).

Milk protein concentrate (MPC) is a concentrated milk product containing $40-90 \%$ of milk protein and sodium caseinate $(\mathrm{NaCN})$ consisting mainly of casein. Both are produced by initially separating of whole milk into cream and skim milk. For the MPC, the skim milk is concentrated using ultrafiltration then the product is spray dried. $\mathrm{NaCN}$ is produced from casein that has been precipitated from milk using rennet enzyme. This casein is washed and the purified casein protein is treated with sodium hydroxide to produce a soluble casein compound, $\mathrm{NaCN}$. The addition of MPC (Soukoulis, Panagiotidis, Koureli, \& Tzia, 2007)and NaCN (Isleten \& Karagul-Yuceer, 2006) to the milk base an improve yoghurt texture and reduce syneresis in set yoghurt. Sodium caseinate has a high protein content with emulsification and water binding properties that contribute to the texture of yoghurt (Isleten \& Karagul-Yuceer, 2006).

Yoghurt fermentation time, is influenced by the protein components of yoghurt milk base (Puvanenthiran, Williams, \& Augustin, 2002). The addition of $\mathrm{WPC}$ and $\mathrm{NaCN}$ does reduce the fermentation time (Damin et al., 2009; Lucey, Teo, Munro, \& Singh, 1997), yet the opposite effect has been observed for SMP (Damin et al., 2009). The latter is similar to the finding obtained of Isleten and Karagul-Yuceer (2006), where the addition of dried dairy ingredients including whey isolate, SMP and NaCN did not affect the fermentation time, although these components greatly influenced the yoghurt texture. This may be explained the buffering effect of the increased solids content in yoghurt milk, meaning more acid development by the starter cul- 
tures was necessary to achieve the casein isoelectric point (Lee \& Lucey, 2010).

The influence of fortification material on the fermentation time may also depend on the starter cultures used (Isleten \& Karagul-Yuceer, 2006). Using a probiotic as single starter culture ( $L$. acidophilus LA5 or L. rhamnosus LR35) fortification of milk bases with SMP, MPC and casein hydrolysate increased the fermentation rate and increased the texture of the yoghurt. This was less pronounced in yoghurt prepared with mixed culture starters (probiotic with $S$. thermophiles) (Sodini, Lucas, Oliveira, Remeuf, \& Corrieu, 2002). For the single culture, the addition of dried dairy ingredient really influenced the fermentation time with the shortest time produced with milk fortified with casein hydrolysate (Oliveira, Sodini, Remeuf, \& Corrieu, 2001; Sodini et al., 2002).

For yoghurt texture, yoghurt fortified with $\mathrm{NaCN}$ is reported to have a stronger gel than the unfortified control and WPI-fortified yoghurts (Isleten \& Karagul-Yuceer, 2006). Yoghurt enriched with $\mathrm{NaCN}$ produced a coarse texture when assessed visually using a spoon (Tamime et al., 1984). This was possibly due to large casein particles and a robust micellar chain. They found the yoghurt firmness made from a milk base fortified with $\mathrm{NaCN}$ was $30 \%$ higher than that from a milk base fortified with SMP, although the former had lower total solid content, $12.8 \%$ rather than $16 \%$. The yoghurt rheology was also influence by the fortification of the milk base with dried dairy ingredients in yoghurt prepared using probiotic cultures (Sodini et al., 2002). They found the highest texture in yoghurt manufactured with added MPC and lowest in yoghurt with added casein hydrolysate. Peng et al. (2009) mentioned that the yoghurt texture based on physicochemical properties related to the nature and type of protein interactions are not well understood. Possible interactions in the yoghurt are hydrophobic and electrostatic interactions, hydrogen bonding, steric repulsion and dissolution of colloidal calcium phosphate (CCP), which collectively influence the yoghurt physical and rheological properties (Peng et al., 2009). Dissolution or solubilisation of CCP could weakened casein-casein interaction and may contribute to soft gel (Peng et al., 2009). Generally, the casein-based powders are more effective than whey protein products in producing a firmer yoghurt (Bhullar, Uddin, \& Shah, 2002; Dave \& Shah, 1998).

The milk base used may stimulate probiotic growth, providing some advantage in manufacturing yoghurts containing probiotics. For example, casein hydrolysate stimulates the growth of L. acidophilus LA5 (Sodini et al., 2002). Different casein hydrolysates may also have different influences on the growth of starter or probiotic cultures, and this is believed to be due to variations in the amino acid and peptide composition. Two casein hydrolysates $(\mathrm{CH} 1$ contain 73.2 of total nitrogen and $\mathrm{CH} 2,74.6$ ) used to fortify a yoghurt milk base produced different result, with $\mathrm{CH} 2$ producing higher growth of starter culture and shorter fermentation time (Sodini et al., 2002). This could be due to slightly higher total nitrogen content in $\mathrm{CH} 2$. The opposite finding was obtained by several researchers (Isleten \& Karagul-Yuceer, 2006; Soukoulis et al., 2007), with no major effect of milk base fortification on the starter culture growth when using the yoghurt cultures $S$. thermophiles and L. delbrueckii subsp. bulgaricus. In general, the starter and milk base interactions appear to have a major influence on yoghurt manufacture.

\section{Heat treatment}

Heat treatment is one of the crucial stages in yoghurt manufacture. The major purpose of heating is to eliminate all the pathogenic and spoilage microorganisms. In addition, the destruction of competitive microorganisms provides a favourable condition for yoghurt bacteria to grow (Chandan \& O'Rell, 2006). In the industry, the yoghurt mix is usually heated at $90^{\circ} \mathrm{C}$ with a minimum holding time of $30 \mathrm{~min}$ (N. Kusumaningrum, personal communication, May 10, 2009). For a high temperature-short time (HTST) pasteurization, the equivalent temperature and time combination is $73^{\circ} \mathrm{C}$ for $15 \mathrm{~s}$, while ultra-high temperature (UHT) treatment uses temperatures more than $90^{\circ} \mathrm{C}$ and as high as $148^{\circ} \mathrm{C}$ for $2 \mathrm{~s}$ (Chandan \& Shahani, 1993). Treatment at $90-95^{\circ} \mathrm{C}$ with a holding time of 5-10 min has also been found to be satisfactory (Labropoulos, Palmer, \& Lopez, 1981; Mottar, Bassier, Joniau, \& Baert, 1989; Parnell-Clunies, Kakuda, 
\& Deman, 1986; Schmidt, Vargas, Smith, \& Jezeski, 1985). In yoghurt manufacture it is important that $70-95 \%$ of the whey protein is denatured to enhance water absorption. This ensures yoghurt with a smooth consistency and high viscosity (Chandan \& O'Rell, 2006). The heat treatment of the yoghurt mix is normally achieved using industrial heat exchangers.

Heating milk also needed for changes in the physicochemical properties of the milk constituents which are relevant in yoghurt making (Tamime \& Robinson, 2007). $\beta$-lactoglobulin, is the main whey protein that is denatured during heating (Lee \& Lucey, 2010). This shifts the yoghurt gelation point towards higher $\mathrm{pH}$ values (Lucey, Tamehana, Singh, \& Munro, 1998), producing a higher isoelectric point at $\mathrm{pH}$ 5.3. Denaturation of $\beta$-lactoglobulin up to $60 \%$ influences the yoghurt texture. Further denaturation, between 60 to $90 \%$ of $\beta$-lactoglobulin, has less effect on the yoghurt texture. Therefore, the heat treatment of milk base contributes to the fermentation time (Labropoulos et al., 1981; Parnell-Clunies et al., 1986; Shaker, Jumah, \& Abu-Jdayil, 2000) and firmness of yoghurt (Augustin, Cheng, \& Clarke, 1999; Dannenberg \& Kessler, 1988).

The use of UHT as a heat treatment for the yoghurt milk base is not common. Yet, the sterilization effect of UHT is vital to prevent the growth of contaminating bacteria during the longer fermentation necessary for the production of MIT yoghurt. UHT can destroy all microorganisms including spores, inactivate some enzymes and affect the chemical changes, colour and flavour of milks (Fox, Mcsweeney, \& Paul, 1998), producing an astringency flavour (Harwalkar, Boutinmuma, Cholette, Mckellar, \& Emmons, 1989). UHT of milk is a continuous heating process at 135 to $150^{\circ} \mathrm{C}$ for $2-8 \mathrm{sec}$ (Krasaekoopt, Bhandari, \& Deeth, 2003) and can be direct or indirect. Most studies use indirect UHT processes. This is due to a better texture and viscosity of yoghurt produced using the indirect compared with the direct method (Mottar et al., 1989).

There are several advantages in using UHT for yoghurt manufacture (1) better process control and sanitation, (2) energy and time savings, (3) high microbial quality, (4) longer shelf-life for the product (Labropoulos et al., 1981; Schmidt et al., 1985) and (5) stimulation of the growth and activity of yoghurt cultures (Smith, Schmidt, \& Adams, 1982). The quality of yoghurt made from UHT milk compared with conventionally heated milk has been extensively reviewed by Krasaekoopt et al. (2003) (Table 2).

Briefly, yoghurt made from UHT milk has (a) lower viscosity and gel strength, (b) less syneresis, (c) a similar flavour to product manufactured from a pasteurized milk base, (d) minor differences in the microstructure (e) different texture that might be due to different denaturation effects of UHT heating and conventional heating on the whey protein, (f) improved texture when fortified with SMP, (e) enhanced the pH reduction (De Brabandere \& De Baerdemaeker, 1999).

\section{Starter culture composition}

The commercial process of yoghurt manufacture uses a defined mixture of lactic acid bacteria. The combination of Streptococcus thermophiles and Lactobacillus delbrueckii subsp. bulgaricus (STLB) is normally used as the starter culture. These starter cultures are thermophilic bacteria with an optimum growth at a temperature of 37 to $45^{\circ} \mathrm{C}$, homofermentative and some strains can produce exopolysaccharide (EPS) (Tamime \& Robinson, 2007). The rationale for selecting the combination of starter cultures is to achieve the desired flavour and texture characteristics. The culture is added to the milk base either by direct inoculation using concentrated, frozen or freeze-dried cultures or indirect inoculation using a pre-cultured inoculum at levels from 1 to $5 \%$ (Sodini et al., 2004).

The Codex standard defines yoghurt as a milk product obtained by the fermentation of milk, or products obtained from milk, by the action of suitable microorganisms resulting in a reduction of $\mathrm{pH}$, with or without coagulation (isoelectric precipitation) (FAO/WHO, 2003). The suitable microorganisms for yoghurt, according to Codex, are as follows; symbiotic cultures of $S$. thermophiles and L. delbrueckii subsp. bulgaricus. Alternative yoghurt cultures mentioned in the Codex standard include a mixture of $S$. thermophiles and any Lactobacillus species. More- 
Table 2: Comparison on the quality of yoghurt produced by UHT and pasteurized milk

\begin{tabular}{|c|c|c|}
\hline Evaluation & Yoghurt produced from UHT milk Vs pasteurized milk (conventional) & References \\
\hline Texture (Firmness and/or & $\begin{array}{l}\text { Yoghurt produced using UHT milk has a weaker gel, lower viscosity and } \\
\text { less shear time compared with conventional processes. } \\
\text { Yoghurt made from UHT milk fortified with } 16,18 \text { and } 20 \% \text { of low heat skim } \\
\text { milk powder has delayed gelation with lower viscosity. } 20 \% \text { of the total solids fortified } \\
\text { in UHT milk have a similar viscosity to } 16 \% \text { total solids in conventional processes. }\end{array}$ & $\begin{array}{l}\text { (Labropoulos, Palmer, and Lopez (1981); } \\
\text { Mottar, Bassier, Joniau, and Baert (1989); } \\
\text { (Parnell-Clunies, Kakuda, and Deman (1986); } \\
\text { (Krasaekoopt, Kew, Bhandari, and Deeth (2002); } \\
\text { Krasaekoopt, Bhandari, and Deeth (2004)) }\end{array}$ \\
\hline Microstructure & $\begin{array}{l}\text { The microstructure studied by SEM and TEM shows a minor difference between } \\
\text { yoghurts produced by UHT milk and conventional processing. } \\
\text { In conventional yoghurt, micelles tend to fuse and form a dense network that } \\
\text { may result in firm gel texture and high viscosity. Compared with UHT yoghurt, } \\
\text { the low gel strength and viscosity and loose microstructure could be due to the } \\
\text { filamentous appendages that disrupt the fusion of casein particles by forming } \\
\text { floccules by particle to particle attachment in UHT yoghurt. }\end{array}$ & $\begin{array}{l}\text { (Parnell-Clunies, Kakuda, Deman, and Cazzola (1988); } \\
\text { Parnell-Clunies, Kakuda, and Smith (1987)) }\end{array}$ \\
\hline Syneresis & $\begin{array}{l}\text { UHT yoghurt was observed to have less syneresis compared with } \\
\text { conventionally processed yogurt. } \\
\text { This could be due to the increase in water holding capacity (WHC) by } \\
\text { denaturation, whereas increased exposure of charged groups and increased } \\
\text { surface area enhances protein-water interactions. }\end{array}$ & $\begin{array}{l}\text { (Savello and Dargan (1997); } \\
\text { Schmidt, Vargas, Smith, and Jezeski (1985)) } \\
\text { Kinsella (1984); } \\
\text { Parnell-Clunies, Kakuda, and Deman (1986)) }\end{array}$ \\
\hline Denaturation of whey protein & $\begin{array}{l}\text { UHT processing was reported to produce less denature whey protein } \\
\text { compared to conventional process. } \\
\text { UHT and conventionally heated milk are observed to have similar levels } \\
\text { of denaturation of whey protein }\end{array}$ & $\begin{array}{l}\text { (Labropoulos, Palmer, and Lopez (1981); } \\
\text { Krasaekoopt, Bhandari, and Deeth (2004)) } \\
\text { (Dargan and Savello (1990); } \\
\text { Mottar, Bassier, Joniau, and Baert (1989) }\end{array}$ \\
\hline
\end{tabular}

over, other microorganisms than those constituting the specific starter culture(s) specified above may be added (FAO/WHO, 2003).

Many types of lactobacilli and bifidobacteria have been used. These bacteria may be added as a probiotic or adjunct culture with the standard bacteria for yoghurt manufacture. The selection of the starter cultures can also affect the growth of probiotics, depending on protocooperation, inhibition or competition (Dave \& Shah, 1997; Saxelin et al., 1999). Probiotic bacteria (Lactobacillus spp. e.g. L. acidophilus, L. casei, Bifidobacterium spp. and Enterococcus spp.) are usually added for producing a health promoting yoghurt. Probiotic bacteria have a beneficial effect on intestinal function and promote good health (Sanders, 1999). Some probiotic bacteria are claimed to aid lactose digestion (Vesa et al., 1996), prevent travellers' diarrhoea (Oksanen et al., 1990) and enhance the immune activity (Meydani \& Ha, 2000). Certain levels of probiotic bacteria are required for these functions. For instance, the occurrence of travellers' diarrhoea can be reduced with $10^{9} \mathrm{cfu}^{\mathrm{day}}{ }^{-1}$ of strain $L$. acidophilus GG (Oksanen et al., 1990). Therefore, it is important to maintain a high number of probiotic bacteria in yoghurt after manufacture in order for them to function as probiotics. For yoghurt fermentation time, the yoghurt starter culture of $S$. thermophiles and L. delbrueckii subspp. Bulgaricus produce a very short fermentation time, 2 to $3 \mathrm{~h}$ at 40 to $45^{\circ} \mathrm{C}$ (Tamime \& Robinson, 2007). Yet, most probiotic bacteria grow slowly in milk and the rate of acid production is usually too slow to support adequate fermentation in yoghurt (Shah, 2000). Several other researchers have also reported that probiotic bacteria produce poor acidification in milk when compared to yoghurt starter cultures (Almeida, Tamime, \& Oliveira, 2008; Marshall \& Tamime, 1997; Oliveira et al., 2001; Saxelin et al., 1999; Sodini et al., 2002). This could be due to a lack of proteolytic activity in probiotic bacteria (Klaver, Kingma, \& Weerkamp, 1993; Lucas, Sodini, Monnet, Jolivet, \& Corrieu, 2004). Starter culture composition has a great effect on fermentation time. When the mixed starter culture (S. thermophiles (ST) with probiotic, $L$. acidophilus (STLA) or L. rhamnosus (STLR)) were used, the fermentation time decreased two to three times compared to using a single culture of probiotic bacteria, L. acidophilus (LA) or $L$. rhamnosus (LR) (Dave \& Shah, 1997; Oliveira et al., 2001; Sodini et al., 2002). Sodini et al. (2002) observed that a mixed culture of STLA produced a fermentation time of approximately 4 to $8 \mathrm{~h}$ compared with LA by itself which had a fermentation time of 8 to $13 \mathrm{~h}$. In another study, Damin, Minowa, Alcantara, and Oliveira (2008) found the shortest fermentation time to reach $\mathrm{pH} 4.5$ was obtained with milk fermented by $S$. thermophiles with $L$. bulgaricus $(5.4 \mathrm{~h})$, 
and that the fermentation time was longer time when $S$. thermophiles was co-cultured with $B i$ fidobacterium lactis $(8.3 \mathrm{~h})$ and $L$. acidophilus $(9.3 \mathrm{~h})$; the differences between them were significant $(\mathrm{p}<0.05)$. The combination of STLA was found to extend the yoghurt fermentation to $168 \mathrm{~h}$ when incubated at $25^{\circ} \mathrm{C}$ compared to STLB (Nor-Khaizura et al., 2012).

Probiotics tend to grow slowly in yoghurt milk base, do not compete well with many starter strains and the probiotics show poor stability during storage. This may be due to competition between lactobacilli, slowing the growth of probiotic lactobacilli (Sodini et al., 2002). Mixed cultures of $S$. thermophilus and a probiotic such as $L$. acidophilus showed that the former predominates under all culture conditions used (Dave \& Shah, 1997; Oliveira et al., 2001; Vinderola, Gueimonde, Delgado, Reinheimer, \& los ReyesGavilán, 2000). Probiotic growth was better when a single culture was used instead of a mixed culture (Sodini et al., 2002). However, Dave and Shah (1997) observed no difference in single or mixed culture for L. acidophilus growth.

The starter culture can influence yoghurt firmness (Hassan, Frank, Schmidt, \& Shalab, 1996; Hess, Roberts, \& Ziegler, 1997; Rohm \& Kovac, 1994) depending whether or not the culture strain is an exopolysaccharide (EPS) producer. This is due to the EPS which has a large molecular mass, interacting with casein or physically preventing casein micelles from coming into close contact, therefore, restricting the increase of yoghurt firmness (Sodini et al., 2004). Some probiotic cultures also influence the rheological parameters, with higher values found in yoghurt with the single culture more than with mixed culture (Sodini et al., 2002). This contradicts Oliveira et al. (2001), where they observed the culture composition did not affected the yoghurt texture.

\section{Inoculum level}

The inoculum level of starter culture may influence the acidification process, and consequently the fermentation time (Nor-Khaizura et al., 2012) and yoghurt gelation (Lee \& Lucey, 2004b; Peng et al., 2009). Lowering the inoculum level decreases the acidification rate (Kristo, Biliaderis, \& Tzanetakis, 2003; Sebastiani, Gel- somino, \& Walser, 1998). This also affects the rheology of yoghurt, which decreases under longer fermentation (Kristo et al., 2003). Higher inoculum levels increase the rheology of yoghurt (Lee \& Lucey, 2004b). The permeability, pore size and whey separation of the yoghurt gel is increased with a long fermentation time due to a lower inoculum (Lee \& Lucey, 2004b). However, according to Sodini et al. (2004), the inoculum level has a small effect. Ronnegard and Dejmek (1993) found not much effect on the yoghurt viscosity when the inoculum level varied between 1 to $5 \%$.

\section{Fermentation temperature}

The fermentation temperature affects the yoghurt fermentation time and texture. Fermentation temperatures higher $\left(43.5\right.$ and $\left.45^{\circ} \mathrm{C}\right)$ than the optimal $\left(42^{\circ} \mathrm{C}\right)$ for standard commercial yoghurt cultures, were reported not to affect $\mathrm{pH}$ development compared with lowering the temperature $\left(40.5\right.$ and $\left.39^{\circ} \mathrm{C}\right)$ where the $\mathrm{pH}$ drop slowed (De Brabandere \& De Baerdemaeker, 1999). Lowering the fermentation temperature causes a systematic decrease in the time required to reach the final $\mathrm{pH}$ of 4.5 , which can be explained by a decrease in the metabolic activity of the bacteria (Haque, Richardson, \& Morris, 2001). Mortazavian et al. (2006) observed that fermentation at $37^{\circ} \mathrm{C}$ required approximately $6.17 \mathrm{~h}$, compared with 40 and $44^{\circ} \mathrm{C}$ requiring 5.26 and $4.39 \mathrm{~h}$, respectively. At even lower fermentation temperatures (e.g. $\sim 30^{\circ} \mathrm{C}$ ), the fermentation time can be extended up to $12 \mathrm{~h}$ and good quality of yoghurt is produced (Lucey et al., 1998). Using probiotic bacteria, the fermentation temperature has a similar influence on the $\mathrm{pH}$ reduction in milk. Ostlie, Treimo, and Narvhus (2005) reported after $48 \mathrm{~h}$ of fermentation, depending on probiotic strains (L. aciophilus LA5, L. acidophilus 1748, L. reuteri SD2112, L. johnsonii LA1 and Bifidobacterium animalis $\mathrm{BB} 12), \mathrm{pH}$ decreased from 6.7 to $4.1-5.1$ at a fermentation temperature of $30^{\circ} \mathrm{C}$, to $3.8-4.7$ at $37^{\circ} \mathrm{C}$ and $3.8-4.5$ at $45^{\circ} \mathrm{C}$. Further lowering the fermentation temperature to $25^{\circ} \mathrm{C}$ using the combination of STLA extended the fermentation time to $168 \mathrm{~h}$, but the yoghurt texture was defective (Nor-Khaizura et al., 2012). At the typical fermentation temperature for yo- 
ghurt, $42^{\circ} \mathrm{C}$ or higher, yoghurt has a fast gelation time. This causes the yoghurt gel network to be more prone to rearrangements and these changes may lead to greater whey separation (Lucey, 2001; Mellema, Walstra, van Opheusden, \& van Vliet, 2002). The yoghurt microstructure shows that gels fermented at $42^{\circ} \mathrm{C}$ have less branches, coarser, thinner strands and larger pores compared to gels fermented at $30^{\circ} \mathrm{C}$ (Lucey et al., 1998). Yoghurt incubated at a lower temperature (e.g. $<40^{\circ} \mathrm{C}$ ) has a slightly longer gelation time, and the product is normally firmer, more viscous, less prone to syneresis and with less lumpy or grainy defects on stirring the coagulum during cooling (Lee \& Lucey, 2004a; Lucey, 2002). A few studies observed, that stirred yoghurt viscosity was higher at lower incubation temperatures $\left(<40^{\circ} \mathrm{C}\right)$ compared with higher temperatures $\left(>40^{\circ} \mathrm{C}\right)$ (Lee \& Lucey, 2006; Martin, Skokanova, Latrille, Beal, \& Corrieu, 1999; Sodini et al., 2004). The micrograph structure of yoghurt fermented at lower temperatures showed a highly cross-linked and branch protein network and small pores (Lee \& Lucey, 2003; Lee \& Lucey, 2004b). However, when yoghurt is fermented at lower temperatures (e.g. $25^{\circ} \mathrm{C}$ ) using the probiotic bacteria as co-culture (STLA), the texture was defective compared to yoghurt fermented with the standard co-culture (STLB) (Nor-Khaizura et al., 2012).

\subsection{Possible mechanism of yoghurt gelation during the long fermentation}

During long fermentation, the acidification rate becomes slower. This condition directly increases the yoghurt gelation or coagulation. Lucey et al. (1998) describe the increased coagulation as a two-step phenomenon. Aggregation of heated milk base is expected to begin at higher $\mathrm{pH}$, at about $\mathrm{pH} 5.3$ (isoelectric $\mathrm{pH}$ of $\beta$-lactoglobulin) and continue to $\mathrm{pH} 4.6$ (isoelectric $\mathrm{pH}$ of casein). During the long fermentation time, the elapsed time between these two $\mathrm{pH}$ levels is also long. At the first step of coagulation, the number of bonds created is higher due to the time needed to reach to $\mathrm{pH}$ 4.6. Therefore, at the second step of coagulation, rearrangement (further ag- gregation of strands and clusters) occur in gel network, causing whey separation and the formation of larger pores (Peng et al., 2009). This was exhibited in the microstructure of yoghurt made with a long fermentation time, where large strands and fewer apparent interconnections in the strands were seen compared to the fine structure and more branches in yoghurt prepared over a short fermentation time (Peng et al., 2009). Based on Nor-Khaizura (2013), two possible formulations for MIT set yoghurt and standard set yoghurt were tested for the sensory using trained panelists (descriptive test) and untrained panelists (acceptance test). The finding showed no significant differences $(\mathrm{p}>0.05)$ between the two MIT set yoghurts on descriptive test yet they were significantly different $(\mathrm{p}<0.05)$ to the standard set yoghurt. The yoghurt attribute that assessed were appearance, aroma, texture and taste. For the acceptance test, MIT set yoghurts scored better than standard set yoghurt for overall acceptance.

\section{Tool to assist in preparing an MIT product}

Predictive microbiology or modelling can be used to assist in monitoring and predicting the fermentation as well as designing the best conditions for fermentation to fit with the requirements of an MIT food. Predictive microbiology describes microbial responses to different environmental conditions, which enable an objective evaluation of the effect of processing, distribution and storage operations on the microbiological safety and quality of foods (McMeekin, Olley, Ratkowsky, \& Ross, 2002). Predictive microbiology is cost effective compared to the traditional microbiological testing to determine shelf-life and safety. Whiting (1993) classified predictive food microbiology according to three levels - primary, secondary and tertiary models. Primary models describe the change in the bacterial number with time under particular environmental and cultural conditions. The response can be measured directly by total viable count (TVC), toxin formation, substrate level or metabolic products and indirectly by absorbance, optical density or impedance. This generates information on the 
generation time, lag phase duration, exponential growth rate and maximum population density (Whiting, 1995; Whiting, 1993; Whiting \& Buchanan, 1994). Secondary models describe the response of one or more parameters of the primary model (e.g. generation time) in accordance with one or more changes in cultural or environmental conditions (e.g. pH, water activity, relative humidity, temperature). Tertiary models are the application of one or more primary and secondary models, incorporated into a user-friendly computer package.

The important aspects of practical model development are the range of characteristics investigated (growth, death, survival, toxin formation etc.). Variables consist of temperature, water activity, $\mathrm{pH}$, nitrate concentration, gaseous atmosphere, organic acid or other preservative concentrations (Ross, Dalgaard, \& Tienungoon, 2000). Reproducible responses are important for developing predictive microbiology in order to be able to predict future behaviour (McMeekin et al., 2002).

There are several examples of predictive microbiology research conducted in dairy manufacture. Roupas (2008) reported that statistical modelling accurately predicted curd $\mathrm{pH}$ and moisture during cheese making. The author added that mathematical models that can predict the cell growth and lactic acid production would be very useful in determining the quality of cheese. The modelling provided improved control in gelation during the cooling of rennet casein gels, and the structure and quality of dairy products such as processed cheese (Zhong \& Daubert, 2004).

In yoghurt processing, Soukoulis et al. (2007) and De Brabandere and De Baerdemaeker (1999) proposed the use of predictive modelling as a monitoring system during yoghurt fermentation. Due to the complexity of the fermentation and the many factors involved in yoghurt coagulation, the mechanisms involved remain poorly understood (Peng et al., 2009). Prediction of fermentation is difficult, so it is a common practice to control it empirically (Soukoulis et al., 2007). In industry, $\mathrm{pH}$ measurement is used to control yoghurt manufacture, as acidification is the parameter for monitoring fermentation (De Brabandere \& De Baerdemaeker, 1999).

The fermentation based on $\mathrm{pH}$ reduction could be illustrated with a three phase process 1) lag phase (slow $\mathrm{pH}$ reduction), 2) logarithm phase (rapid $\mathrm{pH}$ reduction) and 3) slowdown of acidification rate (Soukoulis et al., 2007). This three phase process forms a sigmoidal fermentation curve. The curve is dependent on many parameters (De Brabandere \& De Baerdemaeker, 1999) such as the yoghurt milk base, fortification ingredients, heat treatment, starter culture composition and fermentation temperature (Soukoulis et al., 2007). The modified Gompertz model was shown to be excellent to describe the $\mathrm{pH}$ reduction (Soukoulis et al., 2007; De Brabandere \& De Baerdemaeker, 1999) and viscosity development (Soukoulis et al., 2007) during yoghurt fermentation. This supports continuously monitoring $\mathrm{pH}$ during yoghurt fermentation as a useful tool for checking product quality and for predictive or corrective purposes (Soukoulis et al., 2007). Other than modelling, other monitoring systems suggested include a combination of near infrared (NIR) and the electronic nose (Cimander, Carlsson, \& Mandenius, 2002; Navratil, Cimander, \& Mandenius, 2004).

\section{Potential and challenges for yoghurt as an MIT product}

Based on the information on the manufacture of yoghurt presented in this review, should be possible to prepare MIT yoghurt. Yoghurt is an ideal product to investigate the development of MIT fermented foods as the fermentation period and shelf-life for the standard product are relatively short. This means that results from experiments are produced in a relatively short time frame, compared for the ripening of cheese, for example. In addition, using the MIT concept, it is possible to extend the shelf-life and distribution of this relatively short shelf-life product. In order to prepare an MIT product, the fermentation needs to be extended. This may present challenges in terms of the product texture, flavour and possible contamination. Possible ways to overcome these problems are fortification and UHT treatment of the yoghurt base. The MIT process will be best for products that undergo the transformation in the final package. Therefore, it could minimize the hygiene issue during processing in 
the transit. To design and predict the fermentation of yoghurt under different conditions, predictive microbiology or modelling is an appropriate tool.

\section{References}

Almeida, K. E., Tamime, A. Y., \& Oliveira, M. N. (2008). Acidification rates of probiotic bacteria in minas frescal cheese whey. $L W T$ Food Science and Technology, 41(2), 311316. doi:10.1016/j.lwt.2007.02.021

Amatayakul, T., Sherkat, F., \& Shah, N. P. (2006). Physical characteristics of set yoghurt made with altered casein to whey protein ratios and eps-producing starter cultures at 9 and $14 \%$ total solids. Food Hydrocolloids, 20(2-3), 314-324. 7th International Hydrocolloids Conference, Melbourne, AUSTRALIA, AUG 29-SEP 01, 2004. doi:10.1016/j.foodhyd.2005.02.015

Anema, S. G. \& Li, Y. M. (2003). Effect of ph on the association of denatured whey proteins with casein micelles in heated reconstituted skim milk. Journal of Agricultural and Food Chemistry, 51(6), 1640-1646. doi:10.1021/ jf025673a

Anonymous. (2005). Fonterra Gains Anchor, Fresh n Fruity Brands in NZ. Retrieved from http://www.scoop.co.nz/stories / BU0508/S00134.htm

Augustin, M. A., Cheng, L. J., \& Clarke, P. T. (1999). Effects of preheat treatment of milk powder on the properties of reconstituted set skim yogurts. International Dairy Journal, 9(3-6), 415-416. 1997 Hannah Symposium on Caseins and Caseinates -Structures, Interactions, Networks, HANNAH RES INST, AYR, SCOTLAND, MAY 21-23, 1997. doi:10 . $1016 /$ S0958-6946(99)00113-2

Bhullar, Y. S., Uddin, M. A., \& Shah, N. P. (2002). Effects of ingredients supplementation on textural characteristics and microstructure of yoghurt. MilchwissenschaftMilk Science International, 57(6), 328-332.

Chandan, R. C. \& O'Rell, K. R. (2006). Principles of yogurt processing. In A. K. R. C. Chandan C. H. White \& Y. H. Hui
(Eds.), (Chap. Manufacturing Yogurt and Fermented Milks, pp. 195-209). Oxford, England: Blackwell Publishing.

Chandan, R. \& Shahani, K. M. (1993). Dairy science and technology handbook. In Y. H. Hui (Ed.), (Chap. Yogurt, pp. 1-56). VCH Publishers Inc., New York.

Cho, Y. H., Lucey, J. A., \& Singh, H. (1999). Rheological properties of acid milk gels as affected by the nature of the fat globule surface material and heat treatment of milk. International Dairy Journal, 9(8), 537545. doi:10.1016/S0958-6946(99)00123-5

Cimander, C., Carlsson, M., \& Mandenius, C. F. (2002). Sensor fusion for on-line monitoring of yoghurt fermentation. Journal of Biotechnology, 99(3), 237-248. 10th European Congress of Biotechnology (ECB10), MADRID, SPAIN, JUL, 2001. doi:10.1016/ S0168-1656(02)00213-4

Damin, M. R., Alcantara, M. R., Nunes, A. P., \& Oliveira, M. N. (2009). Effects of milk supplementation with skim milk powder, whey protein concentrate and sodium caseinate on acidification kinetics, rheological properties and structure of nonfat stirred yogurt. LWT-Food Science and Technology, 42(10), 1744-1750. doi:10.1016/j.lwt.2009. 03.019

Damin, M. R., Minowa, E., Alcantara, M. R., \& Oliveira, M. N. (2008). Effect of cold storage on culture viability and some rheological properties of fermented milk prepared with yogurt and probiotic bacteria. Journal of Texture Studies, 39(1), 40-55. doi:10.1111/j.1745-4603.2007.00129.x

Damodaran, S. (1996). Food chemistry. In O. R. Fennema (Ed.), (Chap. Amino Acids, Peptides and Proteins, pp. 245-369). Marcel Dekker Inc., New York. Retrieved from http : / / drasalehi . iauq . ac . ir / assets / subdomains / drasalehi / file / Marcel \% 20Dekker,_Food \% 20Chemistry, \%203rd \% 20Edition_ \% 5B1997_ISBN0824793463\% 5D.pdf

Dannenberg, F. \& Kessler, H. G. (1988). Effect of denaturation of beta-lactoglobulin on texture properties of set-style nonfat yogurt .2. firmness and flow proper- 
ties. Milchwissenschaft-milk Science International, 43(11), 700-704.

Dargan, R. A. \& Savello, P. A. (1990). Ultra-high temperature treatment of skim milk and low fat milk for yogurt. Journal of Dairy Science, 73(Supplement 1), 111.

Dave, R. I. \& Shah, N. P. (1997). Viability of yoghurt and probiotic bacteria in yoghurts made from commercial starter cultures. International Dairy Journal, 7(1), 31-41. doi:10.1016/S0958-6946(96)00046-5

Dave, R. I. \& Shah, N. P. (1998). Ingredient supplementation effects on viability of probiotic bacteria in yogurt. Journal of Dairy Science, 81(11), 2804-2816. doi:10.3168/ jds.S0022-0302(98)75839-4

De Brabandere, A. G. \& De Baerdemaeker, J. G. (1999). Effects of process conditions on the ph development during yogurt fermentation. Journal of Food Engineering, 41(34), 221-227. doi:10.1016/S0260-8774(99) 00096-5

Doyle, M. P., Beuchat, L. R., \& Montville, T. J. (1997). Food microbiology : fundamentals and frontiers. Washington, DC : ASM Press. Retrieved from https://trove. nla.gov.au/work/15886054

FAO/WHO. (2003). Codex Standard for Fermented Milks CODEX STAN 243-2003.

Fox, P. F., Mcsweeney, P. L. H., \& Paul, L. H. (1998). Dairy chemistry and biochemistry. Springer.

Guzmán-González, M., Morais, F., Ramos, M., \& Amigo, L. (1999). Influence of skimmed milk concentrate replacement by dry dairy products in a low fat set-type yoghurt model system. i: use of whey protein concentrates, milk protein concentrates and skimmed milk powder. Journal of the Science of Food and Agriculture, 79(8), 1117-1122. doi:10 . 1002 / (SICI ) 1097 0010(199906) 79:8 $\langle 1117::$ AID- JSFA335 $\rangle$. 0. CO $; 2$ - F. eprint: https: / / onlinelibrary. wiley. com / doi / pdf / 10.1002/\%28SICI \% $291097-0010 \% 28199906 \% 2979 \% 3$ A $8 \%$ 3C1117\% 3A \% 3AAID - JSFA335\% 3E3. 0 . CO\%3B2-F

Haque, A., Richardson, R. K., \& Morris, E. R. (2001). Effect of fermentation temperature on the rheology of set and stirred yogurt. Food Hydrocolloids, 15(4-6), 593602. 5th International Hydrocolloids Conference, RALEIGH, NC, SEP 10-15, 2000. doi:10.1016/S0268-005X(01)00090-X

Harwalkar, V. R., Boutinmuma, B., Cholette, H., Mckellar, R. C., \& Emmons, D. B. (1989). Isolation and partial-purification of astringent compounds from ultrahigh temperature sterilized milk. Journal of Dairy Research, 56(3), 367-373. doi:10.1017/ S002202990002882X

Hassan, A. N., Frank, J. F., Schmidt, K. A., \& Shalab, S. I. (1996). Rheological properties of yogurt made with encapsulated nonropy lactic cultures. Journal of Dairy Science, 79(12), 2091-2097. doi:10.3168/jds.S00220302(96) 76582-7

Hess, S. J., Roberts, R. F., \& Ziegler, G. R. (1997). Rheological properties of nonfat yogurt stabilized using lactobacillus delbrueckii ssp bulgaricus producing exopolysaccharide or using commercial stabilizer systems. Journal of Dairy Science, 80(2), 252-263. doi:10.3168/jds. S0022 0302(97) 75933-2

Isleten, M. \& Karagul-Yuceer, Y. (2006). Effects of dried dairy ingredients on physical and sensory properties of nonfat yogurt. Journal of Dairy Science, 89(8), 2865-2872. doi:10.3168/jds.S0022-0302(06)72559-0

Jaworska, A. (2007a). Made in transit: a supply chain concept for on the way growth (Doctoral dissertation, Master Thesis).

Jaworska, A. (2007b). Made in transit: the end of factory? Retrieved from http://www . foodproductiondaily. com / Supply-Chain / Made-in-Transit-The-end-of-the-factory

Jaworska, A. (2008). The future of fungal freshness? Retrieved from http : / / blog . mycology.cornell.edu/? $\mathrm{p}=418$

Jay, J. M. (2000). Modern food microbiology (Sixth). Maryland: Aspen Publishers.

Kailasapathy, K. \& Supriadi, D. (1996). Effect of whey protein concentrate on the survival of lactobacillus acidophilus in lactose hydrolysed yoghurt during refrigerated storage. Milchwissenschaft-milk Science International, 51(10), 565-569.

Kinsella, J. E. (1984). Milk-proteins physicochemical and functional-properties. 
CRC Critical Reviews in Food Science and Nutrition, 21(3), 197-262. doi:10.1080/10408398409527401

Klaver, F. A. M., Kingma, F., \& Weerkamp, A. H. (1993). Growth and survival of bifidobacteria in milk. Netherlands Milk and Dairy Journal, 47(3-4), 151-164.

Kleijnen, J. P. C. \& Van der Vorst, J. G. A. J. (2005). Designing robust and sustainable fresh-food supply chains: improved simulation methodology for reducing waste. $D e-$ partment of Information Systems \& Management/Center for Economic Research, Tilburg University.

Kosikowski, F. \& Mistry, V. (1997). Cheese and fermented milk foods: origins and principles. Cheese and Fermented Milk Foods. F.V. Kosikowski. Retrieved from https : / / books . google . pt / books ? id = EVydtQEACAAJ

Krasaekoopt, W., Bhandari, B., \& Deeth, H. (2003). Yogurt from uht milk: a review. Australian Journal of Dairy Technology, 58(1), 26-29.

Krasaekoopt, W., Bhandari, B., \& Deeth, H. (2004). Comparison of textures of yogurt made from conventionally treated milk and uht milk fortified with low-heat skim milk powder. Journal of Food Science, 69(6), E276-E280.

Krasaekoopt, W., Kew, S. Y., Bhandari, B., \& Deeth, H. C. (2002). Characterization of texture development of yogurt from uht milk during fermentation. In International conference on innovations in food processing tech $\&$ eng (pp. 355-363). AIT, Bangkok.

Kristo, E., Biliaderis, C. G., \& Tzanetakis, N. (2003). Modelling of the acidification process and rheological properties of milk fermented with a yogurt starter culture using response surface methodology. Food Chemistry, 83(3), 437-446. doi:10.1016/S03088146(03)00126-2

Kurmann, J. A. (1984). Aspects of the production of fermented milks. International Dairy Federation.

Labropoulos, A. E., Palmer, J. K., \& Lopez, A. (1981). Whey-protein denaturation of uht processed milk and its effect on rheology of yogurt. Journal of Texture Studies, 12(3), 365-374. doi:10.1111/j. 1745-4603. 1981. tb00545.x

Lankes, H., Ozer, H. B., \& Robinson, R. K. (1998). The effect of elevated milk solids and incubation temperature on the physical properties of natural yoghurt. 53, 510 513.

Lee, W. J. \& Lucey, J. A. (2004a). Rheological properties, whey separation, and microstructure in set-style yogurt: effects of heating temperature and incubation temperature. Journal of Texture Studies, 34(56), 515-536. doi:10.1111/j.1745-4603.2003. tb01079.x

Lee, W. J. \& Lucey, J. A. (2004b). Structure and physical properties of yogurt gels: effect of inoculation rate and incubation temperature. Journal of Dairy Science, 87(10), 3153-3164. doi:10.3168/jds.S00220302(04)73450-5

Lee, W. J. \& Lucey, J. A. (2006). Impact of gelation conditions and structural breakdown on the physical and sensory properties of stirred yogurts. Journal of Dairy Science, 89(7), 2374-2385. doi:10.3168/jds.S00220302(06)72310-4

Lee, W. J. \& Lucey, J. A. (2010). Formation and physical properties of yogurt. AsianAustralasian Journal of Animal Sciences, 23(9), 1127-1136. doi:10.5713/ajas.2010.r. 05

Lee, W.-J. \& Lucey, J. A. (2003). Rheological properties, whey separation, and microstructure in set-style yogurt: effects of heating temperature and incubation temperature. Journal of Texture Studies, 34(56), 515-536.

Lucas, A., Sodini, I., Monnet, C., Jolivet, P., \& Corrieu, G. (2004). Probiotic cell counts and acidification in fermented milks supplemented with milk protein hydrolysates. International Dairy Journal, 14 (1), 47-53. doi:10.1016/S0958-6946(03)00147-X

Lucey, J. A. (2001). The relationship between rheological parameters and whey separation in milk gels. Food Hydrocolloids, 15(4-6), 603-608. 5th International Hydrocolloids Conference, RALEIGH, NORTH 
CAROLINA, SEP 10-15, 2000. doi:10 . 1016/S0268-005X(01)00043-1

Lucey, J. A. (2002). Formation and physical properties of milk protein gels. Journal of Dairy Science, 85(2), 281-294. doi:10. 3168/jds.S0022-0302(02)74078-2

Lucey, J. A., Munro, P. A., \& Singh, H. (1999). Effects of heat treatment and whey protein addition on the rheological properties and structure of acid skim milk gels. International Dairy Journal, 9(3-6), 275-279. 1997 Hannah Symposium on Caseins and Caseinates -Structures, Interactions, Networks, HANNAH RES INST, AYR, SCOTLAND, MAY 21-23, 1997. doi:10 . 1016/ S0958-6946(99)00074-6

Lucey, J. A., Tamehana, M., Singh, H., \& Munro, P. A. (1998). Effect of interactions between denatured whey proteins and casein micelles on the formation and rheological properties of acid skim milk gels. Journal of Dairy Research, 65(4), 555-567. doi:10. 1017/S0022029998003057

Lucey, J. A., Teo, C. T., Munro, P. A., \& Singh, H. (1997). Rheological properties at small (dynamic) and large (yield) deformations of acid gels made from heated milk. Journal of Dairy Research, 64(4), 591-600. doi:10. $1017 /$ S0022029997002380

Marshall, V. M. \& Tamime, A. Y. (1997). Starter cultures employed in the manufacture of biofermented milks. International Journal of Dairy Technology, 50(1), 35-41. doi:10. 1111/j.1471-0307.1997.tb01733.x

Martin, N. C., Skokanova, J., Latrille, E., Beal, C., \& Corrieu, G. (1999). Influence of fermentation and storage conditions on the sensory properties of plain low fat stirred yogurts. Journal of Sensory Studies, 14(2), 139-160. doi:10.1111/j.1745-459X.1999. tb00109.x

McKenna, A. B. (1997). Examination of whole milk powder by confocal laser scanning microscopy. Journal of Dairy Research, 64 (3), 423-432. doi:10.1017/S0022029997002331

McKenna, A. B. \& Anema, S. G. (1993). The effect of thermal processing during whole milk powder manufacture and after its reconstitution on set-yoghurt properties. In Protein and fat globule modifications by heat treatment, homogenization and other technological means for high quality dairy products. idf seminar, munich (germany). FIL-IDF.

McMeekin, T. A., Olley, J., Ratkowsky, D. A., \& Ross, T. (2002). Predictive microbiology: towards the interface and beyond. International Journal of Food Microbiology, 73(23), 395-407. 3rd International Conference on Predictive Modelling in Foods, LEUVEN, BELGIUM, SEP 12-15, 2000. doi:10. 1016/S0168-1605(01)00663-8

Mellema, M., Walstra, P., van Opheusden, J. H. J., \& van Vliet, T. (2002). Effects of structural rearrangements on the rheology of rennet-induced casein particle gels. Advances in Colloid and Interface Science, 98(1), 25-50. doi:10.1016/S0001-8686(01) 00089-6

Meydani, S. N. \& Ha, W. K. (2000). Immunologic effects of yogurt. American Journal of Clinical Nutrition, 71(4), 861-872.

Mortazavian, A. M., Ehsani, M. R., Mousavi, S. M., Reinheimer, J. A., Emamdjomeh, Z., Sohrabvandi, S., \& Rezaei, K. (2006). Preliminary investigation of the combined effect of heat treatment and incubation temperature on the viability of the probiotic micro-organisms in freshly made yogurt. International Journal of Dairy Technology, 59(1), 8-11. doi:10.1111/j.1471-0307.2006. 00216.x

Mottar, J., Bassier, A., Joniau, M., \& Baert, J. (1989). Effect of heat-induced association of whey proteins and casein micelles on yogurt texture. Journal of Dairy Science, 72 (9), 2247-2256. doi:10.3168/jds.S00220302(89)79355-3

Navratil, M., Cimander, C., \& Mandenius, C. F. (2004). On-line multisensor monitoring of yogurt and filmjolk fermentations on production scale. Journal of Agricultural and Food Chemistry, 52(3), 415-420. doi:10 . 1021/jf0304876

Nor-Khaizura, M.-A.-R. (2013). Development and predictive modelling of set yoghurt as a made-in-transit (MIT) product: a thesis presented in partial fulfilment of the requirements for the degree of Doctor of Philosophy in Food Technology at Massey Uni- 
versity, Palmerston North, New Zealand (Doctoral dissertation, Massey University). Retrieved from http:// hdl. handle.net / $10179 / 4678$

Nor-Khaizura, M.-A.-R., Flint, S. H., McCarthy, O. J., Palmer, J. S., Golding, M., \& Jaworska, A. (2012). Development of madein-transit set culture yoghurt: effect of increasing the concentration of reconstituted skim milk as the milk base. International Journal of Food Science and Technology, 47(3), 579-584. doi:10.1111/j.1365-2621. 2011.02880.x

Oksanen, P. J., Salminen, S., Saxelin, M., Hamalainen, P., Ihantola-Vormisto, A., Muurasniemi-Isoviita, L., ... Salminen, E. (1990). Prevention of travellers diarrhoea by lactobacillus GG. Annals of Medicine, 22(1), 53-56.

Oliveira, M. N., Sodini, I., Remeuf, F., \& Corrieu, G. (2001). Effect of milk supplementation and culture composition on acidification, textural properties and microbiological stability of fermented milks containing probiotic bacteria. International Dairy Journal, 11 (11-12), 935-942. doi:10. 1016 / S09586946(01)00142-X

Oneil, J. M., Kleyn, D. H., \& Hare, L. B. (1979). Consistency and compositional characteristics of commercial yogurts. Journal of Dairy Science, 62(6), 1032-1036. doi:10 . 3168/jds.S0022-0302(79)83368-8

Ostlie, H. M., Treimo, J., \& Narvhus, J. A. (2005). Effect of temperature on growth and metabolism of probiotic bacteria in milk. International Dairy Journal, 15(10), 989-997. doi:10.1016/j.idairyj.2004.08.015

Parfitt, J., Barthel, M., \& Macnaughton, S. (2010). Food waste within food supply chains: quantification and potential for change to 2050. Philosophical Transactions of the Royal Society B-biological Sciences, 365 (1554), 3065-3081. doi:10.1098/rstb . 2010.0126

Parnell-Clunies, E. M., Kakuda, Y., \& Deman, J. M. (1986). Influence of heat treatment of milk on the flow properties of yoghurt. Journal of Food Science, 51 (6), 1459-1462. doi:10.1111/j.1365-2621.1986.tb13834.x
Parnell-Clunies, E. M., Kakuda, Y., Deman, J. M., \& Cazzola, F. (1988). Gelation profiles of yogurt as affected by heat-treatment of milk. Journal of Dairy Science, $71(3)$, 582-588. doi:10.3168/jds.S0022-0302(88) 79594-6

Parnell-Clunies, E. M., Kakuda, Y., \& Smith, A. K. (1987). Microstructure of yogurt as affected by heat-treatment of milk. Milchwissenschaft-milk Science International, 42(7), 413-417.

Patocka, G., Cervenkova, R., Narine, S., \& Jelen, P. (2006). Rheological behaviour of dairy products as affected by soluble whey protein isolate. International Dairy Journal, 16(5), 399-405. doi:10.1016/j.idairyj.2005. 05.010

Peng, Y., Serra, M., Horne, D. S., \& Lucey, J. A. (2009). Effect of fortification with various types of milk proteins on the rheological properties and permeability of nonfat set yogurt. Journal of Food Science, $74(9)$, C666-C673. doi:10.1111/j.1750-3841.2009. 01350.x

Penna, A. L. B., Baruffaldi, R., \& Oliveira, M. N. (1997). Optimization of yogurt production using demineralized whey. Journal of Food Science, 62(4), 846-850. doi:10.1111/j . 1365-2621.1997.tb15469.x. eprint: https : / / onlinelibrary. wiley . com / doi / pdf / 10 . 1111/j.1365-2621.1997.tb15469.x

Penna, A. L. B., Converti, A., \& De Oliveira, M. N. (2006). Simultaneous effects of total solids content, milk base, heat treatment temperature and sample temperature on the rheological properties of plain stirred yogurt. Food Technology and Biotechnology, $44(4), 515$.

Puvanenthiran, A., Williams, R., \& Augustin, M. A. (2002, December). Structure and visco-elastic properties of set yoghurt with altered casein to whey protein ratios. 12, 383-391.

Remeuf, F., Mohammed, S., Sodini, I., \& Tissier, J. P. (2003, December). Preliminary observations on the effects of milk fortification and heating on microstructure and physical properties of stirred yogurt. 13, 773782. doi:10.1016/S0958-6946(03)00092-X 
Rohm, H. \& Kovac, A. (1994). Effects of starter cultures on linear viscoelastic and physical properties of yogurt gels. Journal of Texture Studies, 25(3), 311-329. doi:10.1111/ j.1745-4603.1994.tb00763.x

Rohm, H. \& Schmid, W. (1993, January). Influence of dry matter fortification on flow properties of yogurt. 1. evaluation of flow curves. 48, 556-560.

Ronnegard, E. \& Dejmek, P. (1993). Development and breakdown of structure in yoghurt studied by oscillatory rheological measurements. Le Lait, $73(4), 371-379$.

Ross, T., Dalgaard, P., \& Tienungoon, S. (2000). Predictive modelling of the growth and survival of listeria in fishery products. International Journal of Food Microbiology, 62(3), 231-245.

Roupas, P. (2008). Predictive modelling of dairy manufacturing processes. International Dairy Journal, 18(7), 741-753. Milestone achievements in dairy science research and their current and future industrial applications. doi:10.1016/j.idairyj . 2008.03.009

Sanders, M. E. (1999). Probiotics. food technology. 53, 67-77.

Savello, P. A. \& Dargan, R. A. (1997). Reduced yogurt syneresis using ultrafiltration and very-high temperature heating. Milchwissenschaft, 52(10), 573-577.

Saxelin, M., Grenov, B., Svensson, U., Fondén, R., Reniero, R., \& MattilSvensson, T. (1999). The technology of probiotics. Trends in Food Science \& Technology, 10(12), 387-392. doi:10 . 1016 / S0924 2244(00)00027-3

Schmidt, R. H., Vargas, M. M., Smith, K. L., \& Jezeski, J. J. (1985). The effect of ultrahigh temperature milk processing on yogurt texture1. Journal of Food Processing and Preservation, 9(4), 235-240. doi:10 . 1111/j.1745-4549.1985.tb00723.x

Sebastiani, H., Gelsomino, R., \& Walser, H. (1998). Cultures for the improvement of texture in quarg. In Texture of fermented milk products and dairy desserts-idf symposium, vicenza (italy), 5-6 may 1997. IDF.

Shah, N. P. (2000). Probiotic bacteria: selective enumeration and survival in dairy foods.
Journal of Dairy Science, 83(4), 894-907. doi:10.3168/jds.S0022-0302(00)74953-8

Shaker, R. R., Jumah, R. Y., \& Abu-Jdayil, B. (2000). Rheological properties of plain yogurt during coagulation process: impact of fat content and preheat treatment of milk. Journal of Food Engineering, 44(3), 175180.

Smith, K. L., Schmidt, R. H., \& Adams, J. P. (1982). Growth of yogurt cultures in uht treated milk. Journal of Dairy Science, 65(Suppl 1), 221.

Sodini, I., Lucas, A., Oliveira, M. N., Remeuf, F., \& Corrieu, G. (2002). Effect of milk base and starter culture on acidification, texture, and probiotic cell counts in fermented milk processing. Journal of Dairy Science, 85(10), 2479-2488.

Sodini, I., Remeuf, F., Haddad, S., \& Georges, C. (2004). The relative effect of milk base, starter and process on yogurt texture: a review. Critical Reviews in Food Science and Nutrition, 44(2), 113-137. doi:10.1080/ 10408690490424793

Soukoulis, C., Panagiotidis, P., Koureli, R., \& Tzia, C. (2007). Industrial yogurt manufacture: monitoring of fermentation process and improvement of final product quality. Journal of Dairy Science, 90(6), 26412654. Retrieved from https://www.ncbi. nlm.nih.gov/pubmed/17517704

Spreer, E. (2017). Milk and dairy product technology. Routledge.

Swaisgood, H. E. (1996). Characteristics of milk (O. R. F. F. Chemistry, Ed.). Marcel Dekker.

Tamime, A. Y. \& Deeth, H. C. (1980). Yogurt: technology and biochemistry. Journal of Food Protection, 43(12), 939-977.

Tamime, A. Y., Kalab, M., \& Davies, G. (1984). Microstructure of set-style yoghurt manufactured from cow's milk fortified by various methods. Food Structure, 3(1), 11.

Tamime, A. Y. \& Robinson, R. K. (2007). Tamime and robinson's yoghurt: science and technology. Elsevier.

Trachoo, N. \& Mistry, V. V. (1998). Application of ultrafiltered sweet buttermilk and sweet buttermilk powder in the manufac- 
ture of nonfat and low fat yogurts1. Journal of Dairy Science, 81(12), 3163-3171.

Vesa, T. H., Marteau, P. H., Zidi, S., Briet, F., Pochart, P. H., \& Rambaud, J. C. (1996). Digestion and tolerance of lactose from yoghurt and different semi-solid fermented dairy products containing lactobacillus acidophilus and bifidobacteria in lactose maldigesters-is bacterial lactase important? European Journal of Clinical Nutrition, 50(11), 730-733.

Vinderola, C., Gueimonde, M., Delgado, T., Reinheimer, J., \& los Reyes-Gavilán, C. (2000). Characteristics of carbonated fermented milk and survival of probiotic bacteria. International Dairy Journal, 10(3), 213-220. doi:10 . 1016 / S0958 - 6946(00) 00031-5

Walstra, P. (1999). Dairy technology: principles of milk properties and processes. CRC Press.

Whiting, R. C. (1993). A classification of models in predictive microbiology-a reply to $\mathrm{kr}$ davey. Food Microbiology, 10(2), 175-177.

Whiting, R. C. \& Buchanan, R. L. (1994). Microbial modeling. Food Technology, 48(6), 113-120.

Whiting, R. C. (1995). Microbial modeling in foods. Critical Reviews in Food Science \&6 Nutrition, 35(6), 467-494.

Wilcek, A. (1990). Methods for classification of skim-milk powder. (pp. 135-140). Brussels, Belgium: International Dairy Federation.

Zhong, Q. \& Daubert, C. (2004). Kinetics of rennet casein gelation at different cooling rates. Journal of Colloid and Interface Science, 279(1), 88-94. doi:10.1016/j. jcis . 2004.06.059 